\title{
Chromatographic Characterization of Products Isolated from Chrome Shavings
}

\author{
Edivaldo E.Garcia ${ }^{1}$, Cláudia C.M.Kimura ${ }^{1}$, Ariovaldo C.Martins ${ }^{2}$, Gisele O. Rocha ${ }^{2}$ and \\ Jorge Nozaki* \\ ${ }^{1}$ Mestres em Química (Mestrado em Quimica Aplicada-UEM) ${ }^{2} \mathrm{CNPq} /$ RHAE/biotechnology-Brazil fellowships. (*) \\ Departamento de Química, Universidade Estadual de Maringa Av. Colombo, 5790.87020-900 Maringa, Parana, \\ Brazil.
}

\begin{abstract}
Gel permeation chromatography and high performance liquid chromatography were employed for separation and chemical characterization of products isolated from chrome shavings. After enzymatic hydrolysis, the products isolated were peptides of higher molecular weight. Peptides of lower molecular weight and free aminoacids were the main products using sulfuric acid in chrome shavings solubilization. Glycine (17\%), glutamic acid (10.6\%), alanine (9.2\%), and arginine (8.2\%) were the principal amino acids found. Phenylalanine(1.8\%) was the main aromatic amino acid, while tryptophane was completely absent.
\end{abstract}

Key words; Chrome shavings; enzyme; chromatography; protein, chromium

\section{INTRODUCTION}

Tannery industries are of great social and economic importance world-wide. In Brazil, about 600 industries produce approximately 22 million leather per year, approximately $10 \%$ of total world production (Kimura et al, 1996; Taylor et al., 1996). Tanneries use different types of processes to tan the leather, and tanning with chromium salts are of great environmental concern because of its byproducts (Taylor et al,1991). Enzymatic pocessing of chrome shavings has been shown to be a viable treatment for complete solubilization. Various alkalinity-inducing agents such as magnesium oxide, calcium hydroxide, sodium carbonate, sodium hydroxide,etc.,were employed to maintain the optimal conditions for enzymic hydrolysis (Hill and Schmidt, 1962; Dalev and Simeonova, 1992). Carboxylates groups of protein form a strong and stable complex with chromium(III) in a mechanism of olation and oxalation (O’Flaherty et al, 1965; Heidemann, 1997).
Due to this stable complex, the complete removal of chromium(III) from the soluble protein is a very difficult task, and high content of chromium is deleterious to the enzyme action (Kimura et al, 1996). The soluble protein may have commercial use as gelatines, animal feed supplement, peptides or amino acids production (Boushy et al, 1991; Tingda et al, 1992; Brown et al., 1994; Ta ylor et al., 1998). Chromium recovered after washing may be recycled by tanning industry or used in other industrial applications (Collivgnarelli and Barducci, 1991; Taylor et al., 1998).

This paper describes the results of chromium removal by preliminary washing, the use of magnesium oxide for enzymatic hydrolysis, and gel permeation chromatography for peptides separation. High performance liquid chromatography was employed for amino acids separation and characterization.

\footnotetext{
* Author for correspondence
} 


\section{MATERIALS AND METHODS}

\section{Apparatus}

Atomic absorption spectrometer CG-AA-7000$\mathrm{ABC}$ (AAS), with an air-acetylene burner was used for chromium determination after acidic digestion. UV-VIS-Beckman DU-70 spectrophotometer was used for peptides determination (Kimura et al, 1996). Thermostatic bath, Tecnal TE-184, temperature range of 0 to $99^{\circ} \mathrm{C} \pm 1{ }^{\circ} \mathrm{C}$ was used for chrome shavings hydrolysis. High performance liquid chromatography of amino acids separation was performed with HPLC-LDC-Analytical (Pickering Laboratories, Inc.) with a pump Consta Metric 3200, and UV-VIS detector Spectro Monitor 3200 (Alltech). The following columns were also used: Sodium cation exchange $(8 \mu \mathrm{m}, 3 \times 200 \mathrm{~mm})$, (Pickering Laboratories, Inc.), and a pre-column $(8 \mu \mathrm{m}, 2$ x $200 \mathrm{~mm}$ ).

\section{Reagents}

Proteolytic enzyme Alcalase 2.5 L DX, supplied as a liquid, with activity of 2.5 (Anson unity) and optimal activity at $\mathrm{pH}$ 8.5-9.5 (Nova Nordisk S/A-Brazil); Biuret reagent (BioclinQuibasa); standard solution of protein mixture IV (12300-78000 Daltons-Merck); standard solution of $0.01 \mathrm{~mol} / \mathrm{L}$ of DL-amino acids (Aldrich); Sephadex gel G-10, G-15, and G-75 (Pharmacia Fine Chemicals); $0.4 \%(\mathrm{~m} / \mathrm{v})$ solution of blue dextran (Sigma); $0.2 \%(\mathrm{~m} / \mathrm{v})$ solution of ninhydrin (Sigma) dissolved in acetone; $0.02 \%(\mathrm{~m} / \mathrm{v})$ solution of sodium azide (Aldrich); $0.0625 \mathrm{~mol} / \mathrm{L}$ solution of (TRIS) tris(hydroximethyl)aminomethane (Sigma); $2 \%(\mathrm{~m} / \mathrm{v})$ solution of oxalic acid (merck); $10 \%(\mathrm{v} / \mathrm{v})$ solution of sulfuric acid (Merck).

\section{Sample collection and preparation}

Chrome shavings were collected directly from the tannery industry located $8 \mathrm{Km}$ northwest of Maringa County, Parana State, Brazil. Small pieces of blue chrome shavings were dried at room temperature, exposing directly to the sun during 5 or $6 \mathrm{~h}$. The preliminary washing step was performed with $2 \%(\mathrm{~m} / \mathrm{v})$ solution of oxalic acid in thermostatic bath at $50^{\circ} \mathrm{C}$ and $2 \mathrm{~h}$ with shaking (Kimura et al, 1996). After removal of chromium, the leather solubilization by chemical and enzymatic methods were performed according to the Figures 1 and 2.

Sun dried chrome shavings (2.500g) were transferred to the $250 \mathrm{~mL}$ flask with $75 \mathrm{~mL}$ of distilled water in a thermostatic bath at $50^{\circ} \mathrm{C}$. After $2 \mathrm{~h}$, the solid was filtered using qualitative filter paper (Figure 1). A solution of $6 \mathrm{M}$ sodium hydroxide was added to the filtrate (branch B) until $\mathrm{pH} \mathrm{10,} \mathrm{in} \mathrm{order} \mathrm{to} \mathrm{precipitate}$ $\mathrm{Cr}(\mathrm{OH})_{3}$. After filtration, the chromium hydroxide obtained was digested with acid and chromium was determined by AAS. The solid residue (branch A) was treated with 3\% magnesium oxide (w/v) and $10 \%$ sodium carbonate at $25^{\circ} \mathrm{C}$ for $24 \mathrm{~h}$. The sample was then treated with $1 \%$ enzyme at $60^{\circ} \mathrm{C}$ for $2 \mathrm{~h}$. After this treatment, the chrome shavings were almost dissolved producing a viscous yellow solution. The filtrate was separated in three portions for the following experiments: a) protein determination by Biuret's method (Smith,1985); b) acidic digestion and protein determination by Kjeldhal's method (Standard Methods for the Examination of Water and Wastewater, 1992); c) acidic digestion and chromium determination by AAS, as shown in Figure 1.

The same amount of sun dried chrome shavings were transferred to a $250 \mathrm{~mL}$ flask with $75 \mathrm{~mL}$ of distilled water at $50^{\circ} \mathrm{C}$ and left for $2 \mathrm{~h}$ (Figure 2). After filtration and separation of filtrate (branch B), the residue (branch A) was washed with 40,50 , and $60 \mathrm{~mL}$ of $10 \%$ sulfuric acid at $25,40,50$, and $60^{\circ} \mathrm{C}$ with shaking time of 30 , 60 , 90, and 120 minutes respectively. The filtration was performed with separation of a blue residue that after acidic digestion was used for chromium determination by AAS. A solution of $6 \mathrm{M} \mathrm{NaOH}$ was added to the filtrate until $\mathrm{pH}$ 10, and kept overnight. After filtration, the solid 
$\mathrm{Cr}(\mathrm{OH})_{3}$ was kept at $600^{\circ} \mathrm{C}$ for $2 \mathrm{~h}$, and after acidic digestion the chromium oxide was determined by AAS. Proteins were also determined by Biuret and Kjeldhal's methods after acidic digestion of filtered solutions (Figure 2). The filtrate in branch B was treated in the same way as branch B in Figure 1. The final soluble protein shown were used for peptides separations using gel permeation chromatography, and also for amino acids analysis after acidic hydrolysis.

\section{Chromatographic separation}

Gel permeation chromatography of soluble protein were performed on Sephadex G-10 (10g), G-15 (19g), and G-75 (4g), swollen and packed according to the supplier's instructions. An aliquot of $1.0 \mathrm{~mL}$ of soluble protein was applied to the top of the column and after the sample had entered the gel bed, it was eluted with $0.02 \%$ solution of sodium azide. Absorbance at 235 and $280 \mathrm{~nm}$ were measured using $1 \mathrm{~cm}$ quartz cubets. The void volume $\left(\mathrm{V}_{0}\right)$ was determined from the elution of $0.4 \%$ solution of Blue Dextran, reading the absorbance at $620 \mathrm{~nm}$.

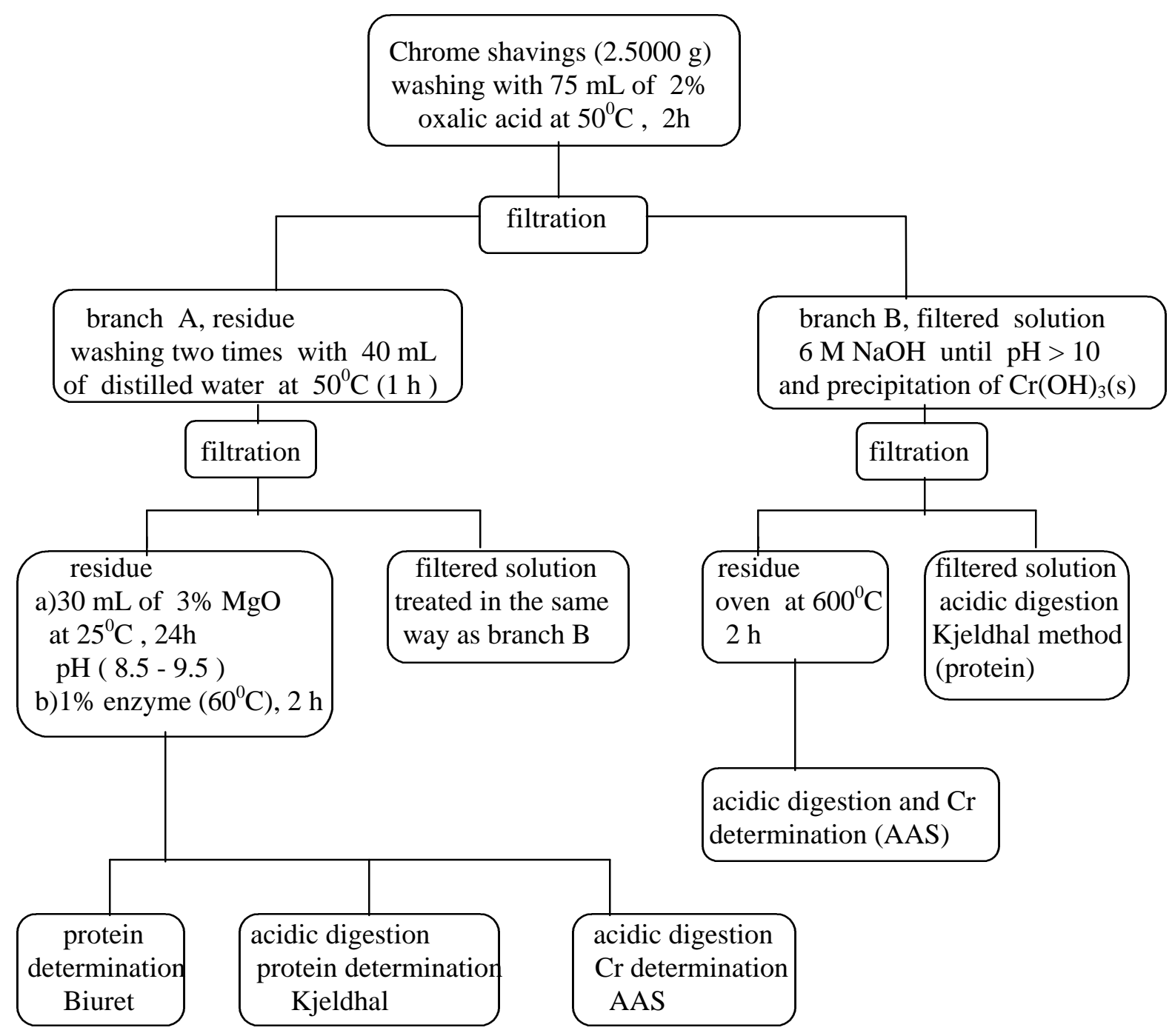

Figure 1. Chrome shavings hidrolysis with proteolytic enzyme and preliminary washing with oxalic acid. 


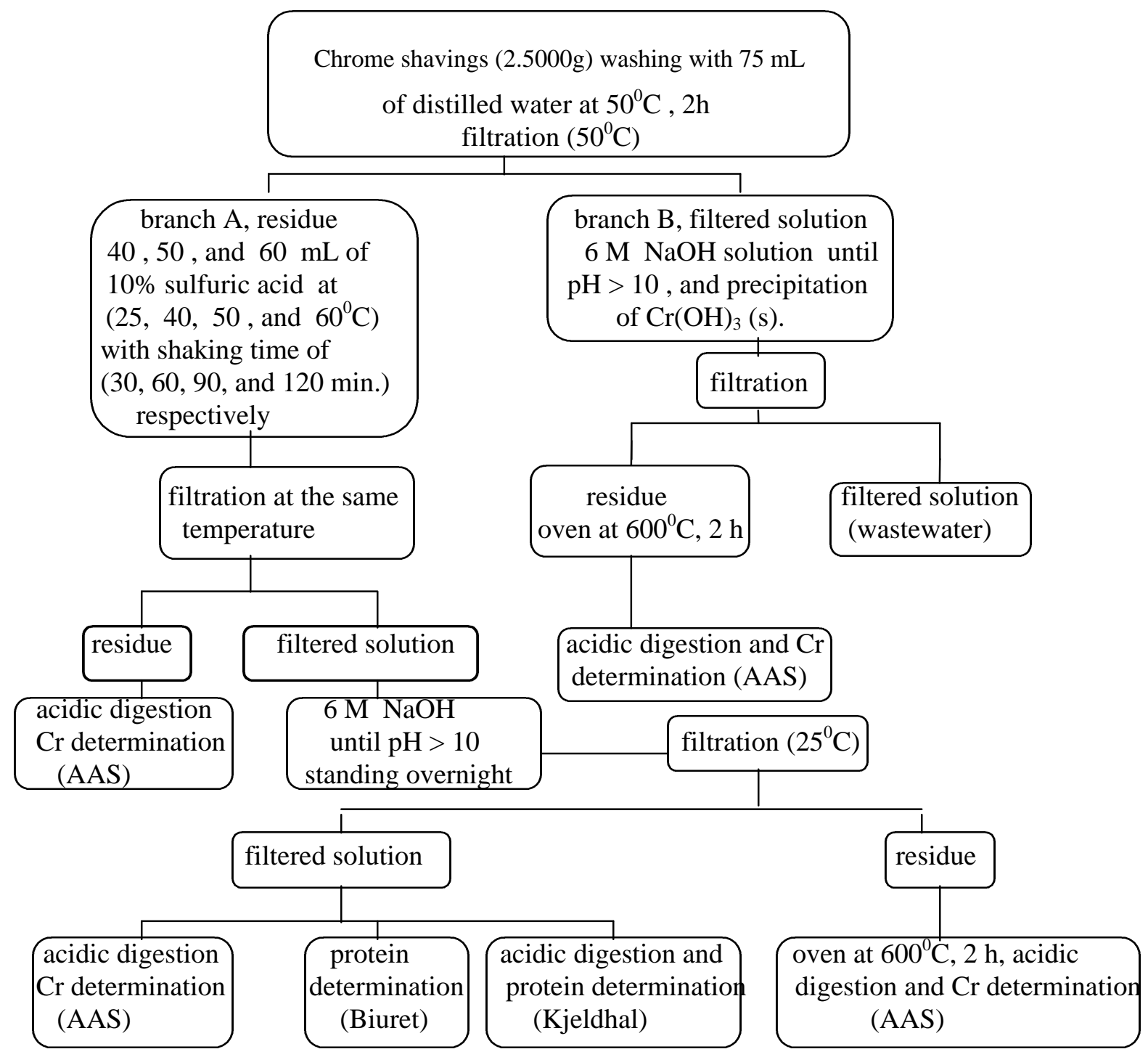

Figure 2. Schematic diagram of chrome shavings hydrolysis using sulfuric acid instead of proteolytic enzyme

The total volume $\left(\mathrm{V}_{\mathrm{t}}\right)$ was determined with a 30 $\mu \mathrm{L} / \mathrm{mL}$ acetone, reading the absorbance at 264 $\mathrm{nm}$. Partition coefficient $\left(\mathrm{K}_{\mathrm{av}}\right)$ was calculated using a kit of standard proteins (12300 - 78000 $\mathrm{Da})$ with the following equation: $\mathrm{K}_{\mathrm{av}}=\left(\mathrm{V}_{\mathrm{e}}\right.$ $\left.\mathrm{V}_{0}\right) /\left(\mathrm{V}_{\mathrm{t}}-\mathrm{V}_{0}\right)$, where $\mathrm{V}_{\mathrm{e}}$ was used for elution volume. Plot of $K_{a v} \times$ logarithm of molecular weight was linear for molecular weight (Daltons) of 16949 (myoglobin), 30000 (carbonic anhydrase), 42700 (ovalbumin), 66250 (albumin), and 78000 (ovotransferrin).

\section{Sample preparation and amino acids analyses by high performance liquid chromatography (HPLC)}

The hydrolysis of soluble protein was performed using a Teflon tube with an internal volume of $75 \mathrm{~mL}$ by heating at $110^{\circ} \mathrm{C}$ for $36 \mathrm{~h}$ with 6 
$\mathrm{mol} / \mathrm{L} \mathrm{HCl}$ solution. The solution was concentrated by evaporation and the $\mathrm{pH}$ was adjusted to 5.0 - 5.5. HPLC separations were carried out using sodium cation exchange columns at $55^{\circ} \mathrm{C}$ (flow rate $0.3 \mathrm{~mL} / \mathrm{min}$.). Ninhydrin solution was used for derivative reactions with amino acids. The eluents used were: mobile phase A: buffer solution of 0.2 $\mathrm{mol} / \mathrm{L}$ sodium citrate, $\mathrm{pH} 3.25$., mobile phase B: buffer solution of $0.01 \mathrm{~mol} / \mathrm{L}$ sodium phosphate, $\mathrm{pH}$ 7.40. Post-column temperature was $130^{\circ} \mathrm{C}$ with the absorbance reading at $570 \mathrm{~nm}$.

\section{RESULTS AND DISCUSSION}

Figures 1 and 2 show the schematic diagram for chrome shavings washing and hydrolysis. Enzymatic (proteolytic enzyme) and acidic (sulfuric acid) were used for complete hydrolysis of chrome shavings (Kimura et al, 1996). Gel permeation chromatography showed the following peaks (elution volumes) of Blue dextran: $V_{0}=20 \mathrm{~mL}$ with Sephadex G-10,column of $445 \times 11 \mathrm{~mm}$, eluent used was $0.02 \%$ sodium azide solution, flow rate of 0.8 $\mathrm{mL} / \mathrm{min}, \lambda=620 \mathrm{~nm}$. $\mathrm{V}_{0}$ was also $20 \mathrm{~mL}$ for Sephadex G-15 under the same conditions. $V_{0}$ of $12 \mathrm{~mL}$ was found with Sephadex G-75, with a column of $390 \times 13 \mathrm{~mm}$, eluent was $0.02 \%$ sodium azide solution, flow rate of 0.1 $\mathrm{mL} / \mathrm{min}$., and $\lambda=620 \mathrm{~nm}$.

Figure 3 shows chromatographic separation of soluble protein after acidic hydrolysis with sulfuric acid. Figure 4 shows the peptides separations after enzymatic hydrolysis. The volume of $19 \mathrm{~mL}$ shown in both figures indicated the presence of peptides of molecular weight higher than $700 \mathrm{Da}$ (Tayyab et al.,1991). The volume (peak) of $35 \mathrm{~mL}$ that appeared in Figure 3, but not shown in Figure 4, indicated the presence of peptides with lower molecular weight, and also free amino acids (Whitaker et al., 1963). This was an indication that enzymatic hydrolysis produced higher amounts of high molecular weight peptides. The same results were observed using Biuret and Kjeldhal's methods for peptides analyses (Kimura et al,1996) .

Figures 5 and 6 show the gel chromatographic separation of soluble protein with Sephadex G75 after acidic and enzymatic hydrolysis of chrome shavings. Figure 5 shows a peak at 34 $\mathrm{mL}$ for peptides of molecular weight higher than $3000 \mathrm{Da}$, and another peak at $45 \mathrm{~mL}$ not shown in Figure 6, for peptides lower than 3000 Da. Figure 6 shows a peak at $17 \mathrm{~mL}$ for peptides of molecular weight of $51000 \mathrm{Da}$ (Condell et al.,1993) .

Table 1 shows the molecular weight of standard proteins, $\mathrm{V}_{\mathrm{e}}$, and $\mathrm{K}_{\mathrm{av}}$ calculated as discussed previously. Table 2 shows the amino acids content after solubilization of chrome shavings, and acidic hydrolysis of soluble protein. The contents of amino acids found in this work by HPLC were closely related to the values found by other authors (Table 2) (Reis et al.,1989;Boushy et al.,1991; Taylor et al.,1991). The values found by Tingda (1992), were lower, except for cystine and tyrosine, probably due to the methods employed for chrome shavings solubilization.

\section{CONCLUSIONS}

The products recovered after enzymatic hydrolysis of chrome shavings were peptides of higher molecular weight when compared with acidic hydrolysis. Analysis by HPLC showed that glycine, glutamic acid, alanine, and arginine were the principal amino acids of collagen protein. The main aromatic amino acid that showed strong absorption at $280 \mathrm{~nm}$ was phenylalanine, while tryptophan was completely absent. 
Table 1. Molecular weight, volume of eluent ( $\mathrm{V}_{\mathrm{e}}, \mathrm{mL}$ ), and $\mathrm{K}_{\mathrm{av}}$ of standard proteins.

\begin{tabular}{lccc}
\hline Protein & molecular weight (Daltons) & $\mathrm{V}_{\mathrm{e}}(\mathrm{mL})$ & $\mathrm{K}_{\mathrm{av}}$ \\
\hline Citochrome C & 12384 & 38 & 1.00 \\
Myoglobin & 16949 & 24 & 0.46 \\
Carbonic anhydrase & 30000 & 20 & 0.31 \\
Ovalbumin & 42700 & 18 & 0.23 \\
Albumin & 66250 & 16 & 0.15 \\
Ovotransferrin & 78000 & 14 & 0.08 \\
\hline
\end{tabular}

Experimental conditions: Column of ( $390 \times 13 \mathrm{~mm}$ ), Sephadex G-75, eluent used was a buffer solution of TRIS-HCl ( $\mathrm{pH}$ 6.8 ), and flow rate of $0.1 \mathrm{~mL} / \mathrm{min}$. The $\mathrm{V}_{0}$ used was $12 \mathrm{~mL}$ found using Blue dextran. The total volume $\mathrm{V}_{\mathrm{t}}$ used was $38 \mathrm{~mL}$ measured using acetone.

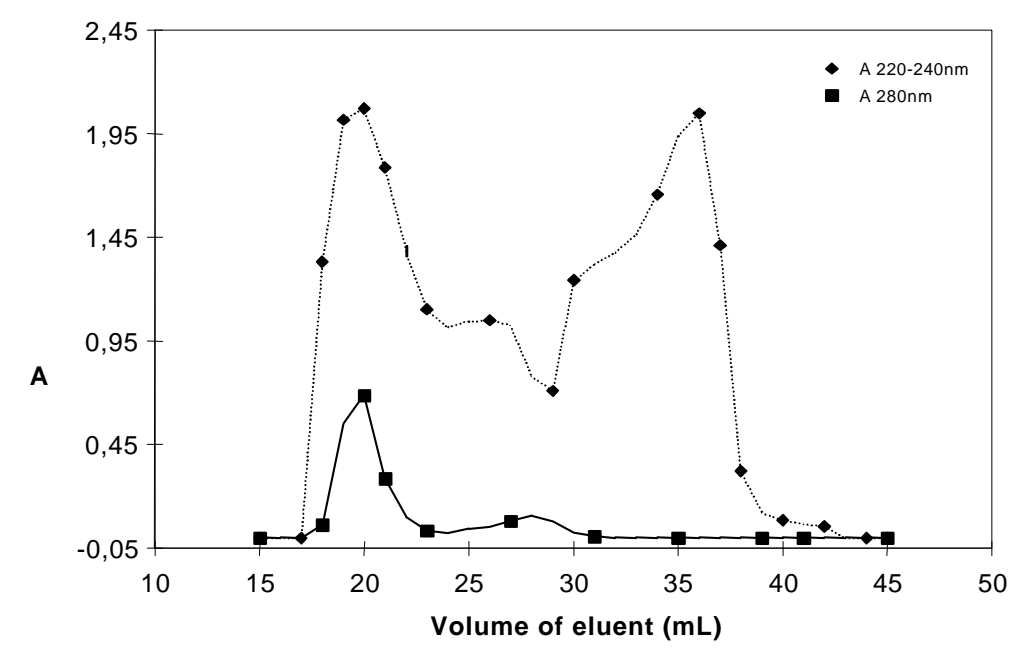

Figure 3: Separation using Sephadex G-10 of soluble protein treated with sulfuric acid. Absorbance $\mathrm{x}$ volume of eluent. Dashed line ( $\lambda=235 \mathrm{~nm})$, black line $(\lambda=280 \mathrm{~nm})$.

Experimental conditions: Eluent ( $0.02 \%$ sodium azide solution ). Column: Sephadex G-10 (40$120 \mu \mathrm{m}),(44.5 \times 1.3 \mathrm{~cm})$. Flow rate: $0.8 \mathrm{~mL} / \mathrm{min}$.

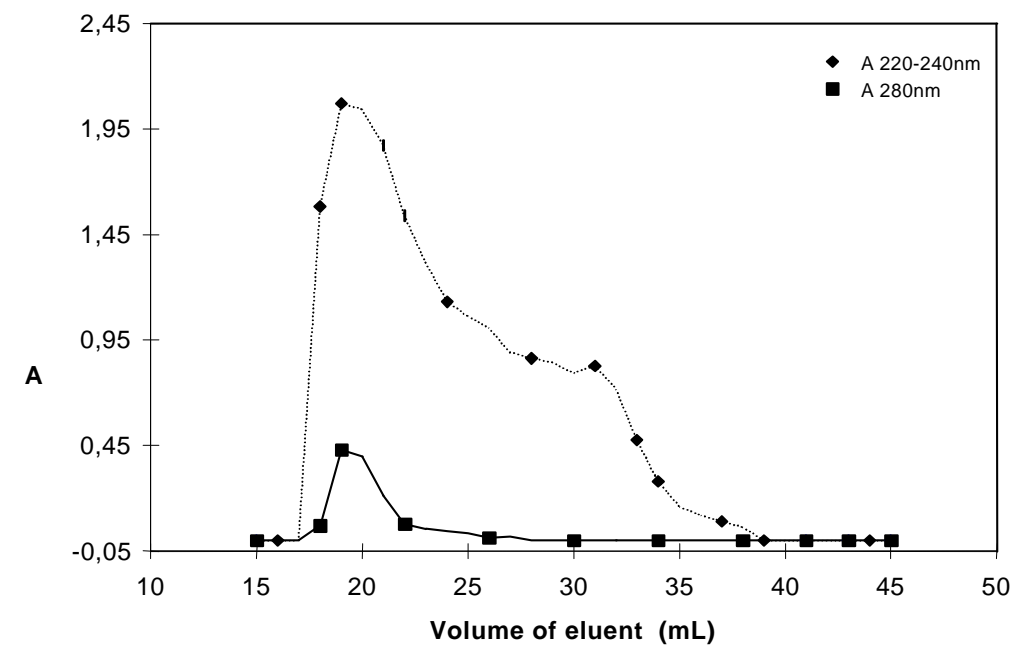

Figure 4: Separation using Sephadex G-10 of soluble protein treated by enzymatic method. Absorbance $x$ volume of eluent. Dashed line $(\lambda=235 \mathrm{~nm})$, black line $(\lambda=280 \mathrm{~nm})$.

Experimental conditions: Column: Sephadex G-10 $(40-120 \mu \mathrm{m}),(44.5 \times 1.3 \mathrm{~cm})$. Eluent: sodium azide solution $(0.02 \%)$. Flow rate: $0.8 \mathrm{~mL} / \mathrm{min}$. 


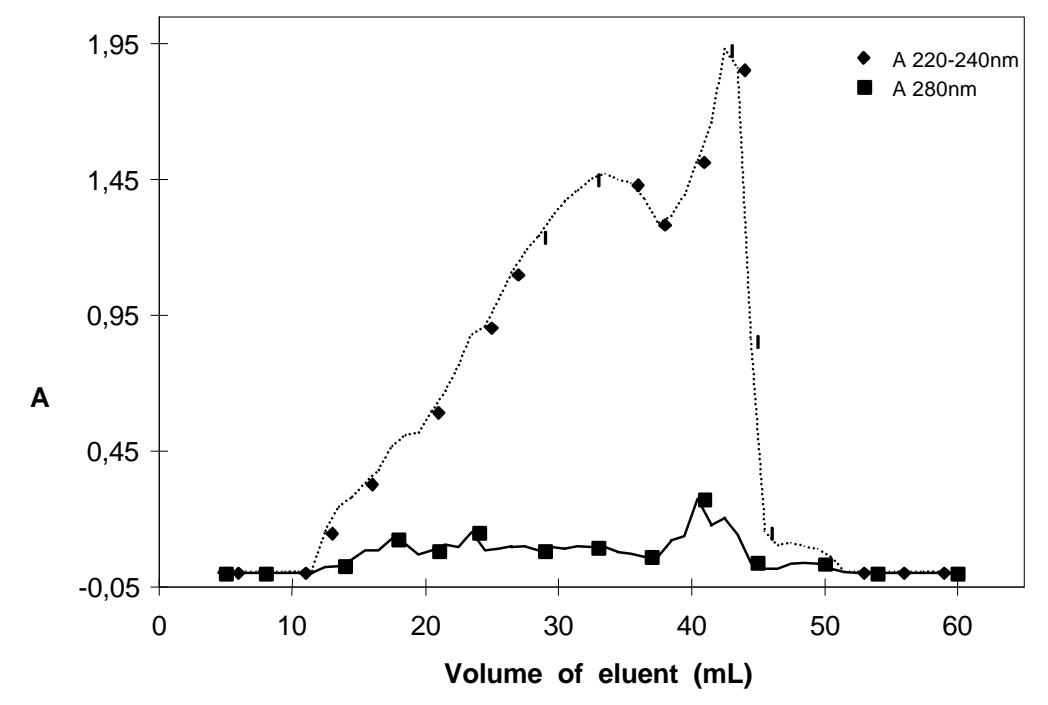

Figure 5: Separation using Sephadex G-75 of soluble protein treated with sulfuric acid. Absorbance $x$ volume of eluent. Dashed line ( $\lambda=235 \mathrm{~nm})$, black line $(\lambda=280 \mathrm{~nm})$.

Experimental condition: Column: Sephadex G-75 $(20-50 \mu \mathrm{m}),(39.0 x 1.3 \mathrm{~cm})$.

Eluent: Sodium azide solution $(0.02 \%)$. Flow rate: $0.1 \mathrm{~mL} / \mathrm{min}$.

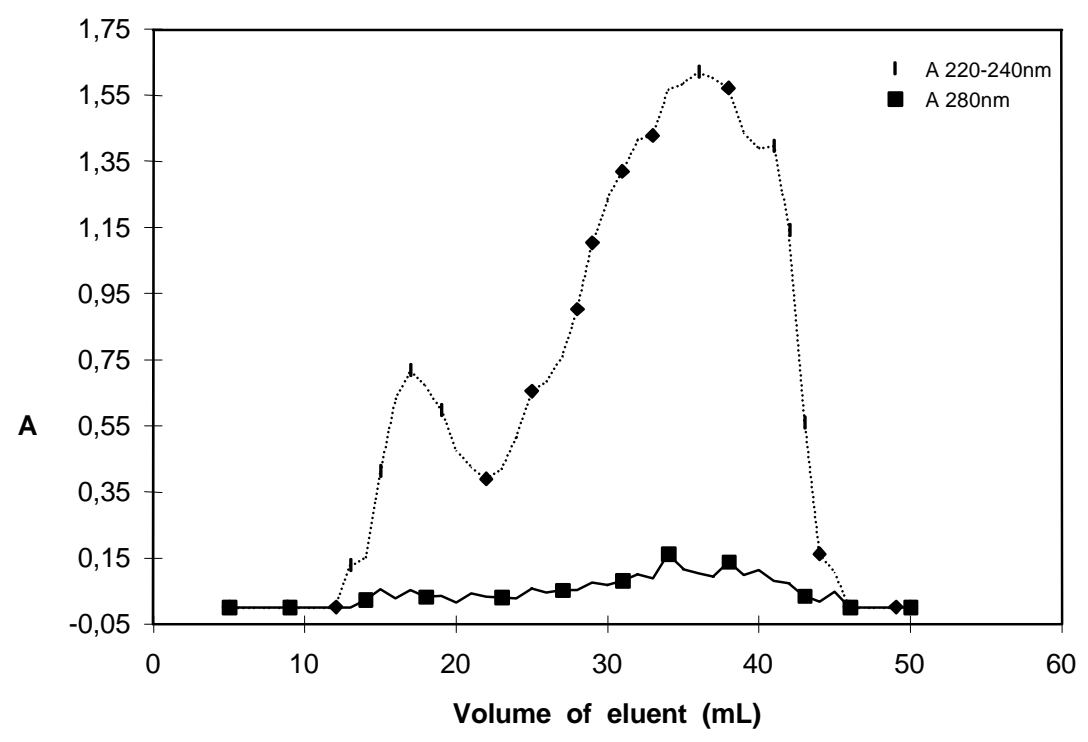

Figure 6: Separation using Sephadex G-75 of soluble protein treated by enzymatic method. Absorbance $x$ volume of eluent. Dashed line ( $\lambda=235 \mathrm{~nm})$, black line $(\lambda=280 \mathrm{~nm})$.

Experimental condition: Column: Sephadex G-75 $(20-50 \mu \mathrm{m}),(39.0 \times 1.3 \mathrm{~cm})$.

Eluent: Sodium azide solution $(0.02 \%)$. Flow rate: $0.1 \mathrm{~mL} / \mathrm{min}$. 
Table 2. Amino acids contents in chrome shavings in \% related to the dry leather.

\begin{tabular}{|c|c|c|c|c|c|}
\hline Amino acids & $\mathrm{A}$ & B & $\mathrm{C}$ & $\mathrm{D}$ & $\mathrm{E}$ \\
\hline Aspartic acid & 4.6 & 2.9 & 4.7 & 5.1 & 4.3 \\
\hline Threonine & 1.8 & 0.8 & 0.8 & 2.1 & 1.3 \\
\hline Serine & 3.2 & 1.4 & 1.3 & 4.1 & 2.6 \\
\hline Glutamic acid & 10.6 & 5.6 & 9.0 & 7.7 & 7.3 \\
\hline Phenylalanine & 1.8 & 1.1 & 1.8 & 1.3 & 1.4 \\
\hline Histidine & 0.7 & 0.4 & 0.5 & 0.9 & 0.6 \\
\hline Glycine & 17.0 & 10.6 & 20.5 & 33.0 & 14.8 \\
\hline Alanine & 9.2 & 4.5 & 9.4 & 8.4 & 6.4 \\
\hline Cystine & 0.1 & 0.3 & ND & ND & ND \\
\hline Valine & 2.2 & 1.5 & 2.1 & 2.4 & 1.7 \\
\hline Lysine & 3.7 & 1.5 & 4.1 & 2.7 & 2.6 \\
\hline Arginine & 8.2 & 3.4 & 6.5 & 4.8 & 5.9 \\
\hline Methionine & 1.3 & 0.3 & 1.0 & 0.2 & 0.6 \\
\hline Isoleucine & 1.4 & 0.9 & 1.3 & 1.4 & 1.2 \\
\hline Leucine & 2.8 & 1.6 & 2.8 & 2.6 & 2.2 \\
\hline Tryptophan & ND & 0.1 & ND & ND & ND \\
\hline Tyrosine & 0.3 & 0.6 & 0.4 & 0.5 & 0.5 \\
\hline \multicolumn{6}{|c|}{$\begin{array}{l}\text { A) Represents the amino acids determined in this work by HPLC. } \\
\text { B) Amino acids found by Tingda et al. } \\
\text { C) Represents the work of Reis et al. } \\
\text { D) Taylor et al. } \\
\text { E) Boushy et al. }\end{array}$} \\
\hline
\end{tabular}

\section{ACKNOWLEDGMENT}

The authors would like to thank FNMA/MMA, CAPES, and $\mathrm{CNPq}$ (Brazil) for the financial support.

\section{RESUMO}

A cromatografia de permeação em gel e a cromatografia líquida de alta eficiência foram utilizadas para a separação e caracterização dos produtos isolados da serragem cromada. Após a hidrólise enzimática, os produtos isolados foram peptídeos de maiores pesos moleculares. Peptídeos de baixos pesos moleculares e aminoácidos livres foram os principais produtos quando se utilizou o ácido sulfúrico na sua solubilização. Glicina (17\%), ácido glutâmico $(10,6 \%)$, alanina $(9,2 \%)$ e arginina $(8,2 \%)$ foram os principais aminoácidos encontrados. $\mathrm{O}$ principal aminoácido aromático foi a fenilalanina $(1,8 \%)$ com a ausência completa do triptofano.

\section{REFERENCES}

Boushy, A.R.E.; Van der Poel, A.F.B.; Koene, J.J.A. \& Dieleman, S.H.(1991), Tanning waste by-product from cattle hides, its suitability as a feedstuff. Bioresource Technology 35, 321-323

Brown, E. M; Thompson, C .J., and Taylor, M.M.(1994), Molecular size and conformation of protein recovered from chrome shavings.The Journal of the American Leather Chemists Association (JALCA) 89 (7)

Collivgnarelli, C. and Barducci, G.(1984), Waste recovery from the tanning industry. Waste Management \& Research 2, 265-278 
Condell, R.A., Hanko,V.P., Larenas, E.A., Wallace,G.,and McCullough,K.A(1993), Analysis of native collagen monomers and oligomers by size-exclusion highperformance liquid chromatography and its application. Analytical Biochemistry 212,436-445

Dalev, P.G. and Simeonova, L.S.(1992), An enzyme biotechnology for the total utilization of leather wastes. Biotechnology letters 14, 6, 531-534

Heidemann, E.(1997), Comparison between chrome tannage and vegetable tannage with regard to number and location of the functional groups of the collagen structure which are involved in crosslinking. Leder 48, (5),99-104

Hill,R.L. and Schmidt,W.R.(1962), The complete Enzymic Hydrolysis of Proteins. The Journal of Biological Chemistry 237, 2, 389-396

Kimura, C.C.M.; Garcia, E.E.; Martins, A.C. and Nozaki, J. (1996), Enzymic solubilization of chrome shavings. Conference on Environmetrics in Brazil. USP/SP

O'Flaherty, F.; Roddy,W.T. and Lollar,R.M. Editors (1965), The Chemistry and Technology of Leather, vol.I-IV, Reinhold Publishing Corp., New York, pp.1956

Reis, M. and Beleza, V.(1989), Utilization of leather waste-animal feedstuff from chrome shavings: part 1,pilot plant study. Journal of the Society of Leather Technologists and Chemistsv 75, 18

Smith, P.K.(1985), Colorimetric method for the determination of protein. Anal. Biochem.,150, 76-78

Standard Methods for the Examination of Water and Wastewater (1992), $18^{\text {th }}$ Edition.Greenberg, A.E., Clesceri, L.S., and Eaton, A.D. Editors, Washington

Taylor, M.M.; Diefendorf, E. J. and Marmer,W.N.(1991), Efficiency of enzymic solubilization of chrome shavings as influenced by choice of alkalinity-inducing agents. The Journal of the American Leather Chemists Association (JALCA ) 86, 5, 199-208

Taylor,M.M.; Diefendorf, E.J.; Thompson, C.J.; Brown, E.M., and Marver, W.N.(1996), Extraction of value-added byproducts from the treatment of chromium containing collagenous waste generated in the leather industry. AQEIC Bol. Tec., (3), 124-150

Taylor, M.; Cabeza, L.F.; DiMaio, G.;Brown, E.M.;Marmer, W.N.; Carrio,R.; Celma, P.J., and Cot,J.(1998), Processing of leather waste: Pilot scale studies on chrome shavings, Part I. Isolation and characterization of protein products and separation of chrome cake. The Journal of the American Leather Chemists Association (JALCA) 93,(3), 61

Tingda, J.; Dihua, Mo; Yiwan, C. and Chumping, Z.(1992), Nutrition of feed collagen protein powder from the reclamation treatment of chrome leather scrap. Animal Feed Science and technology 37, $175-184$

Tayyab, S.,Qamar,S., and Islam, M.(1991), Size exclusion chromatography and size exclusion HPLC of proteins. Biochemical Education 19 (3), 149-152

Whitaker,J.R.(1963), Determination of molecular weights of proteins by gel filtration on Sephadex. Analytical Chemistry 35 (12), 1950-1953

Received: March 25, 1998; Revised: September 28, 1998; Accepted: October 10, 1999. 